\title{
PENGARUH MODEL DISCOVERY LEARNING DENGAN METODE LATERAL THINKING TERHADAP KEMAMPUAN BERTANYA SISWA KELAS X IPA SMAN 2 KARANGANYAR
}

\section{THE EFFECT OF DISCOVERY LEARNING MODEL WITH LATERAL THINKING METHOD ON THE QUESTIONING ABILITY OF THE 10TH IPA GRADERS OF SMAN 2 KARANGANYAR.}

\author{
WENY PUPUT AURLENA, SUCIATI, JOKO ARIYANTO \\ Program Studi Pendidikan Biologi \\ Fakultas Keguruan dan Ilmu Pendidikan \\ Universitas Sebelas Maret \\ Jl. Ir. Sutami 36 A, Surakarta, 57126, Indonesia \\ *Corresponding Author: aurlena31@gmail.com
}

Manuscript received : 11 Januari 2016 Revision accepted: 22 Maret 2016

\begin{abstract}
This research aimed to find out the effect of discovery learning with lateral thinking on questioning ability of the $10^{\text {th }}$ IPA graders of SMAN 2 Karanganyar.This study was a quasi experimental research with post-test only with non-equivalent group research design. The population of research was all of the $10^{\text {th }}$ graders of SMAN 2 Karanganyar. The sampling technique used was cluster sampling one. The $10^{\text {th }}$ IPA 2 grade served as experiment group and the $10^{\text {th }}$ IPA 3 as control. Techniques of collecting data used were test and non-test. Test technique employed essay question instrument to measure the learning outcome in cognitive domain, while nontest technique used observation sheet instrument to measure the students' questioning ability, learning outcome in psychomotor and affective domains and the implementation of learning syntax. Hypothesis testing was carried out using t-test with SPSS version 17 help.The results showed that the ability to ask students between the experimental group and the control group were significantly different . Values experimental group students' ability to ask include: questions asking for an explanation of 1.54 ; The question of what, why and how 36.18 ; background hypothetical question 40.13 . Value KPS control groups included: the question asked for an explanation of 0.57 ; The question of what, why and how 41.03 ; background hypothetical question 29.06 This research concluded that there was an effect of discovery learning model with lateral thinking method on the questioning ability of the $10^{\text {th }}$ IPA graders of SMAN 2 Karanganyar.
\end{abstract}

Keywords: discovery learning, lateral thinking, questioning ability

\section{PENDAHULUAN}

Abad ke-21 membutuhkan generasi pemikir kritis yang mampu memecahkan masalah serta berpartisipasi aktif mengambil keputusan terhadap isu-isu lokal dan global yang dibentuk melalui proses belajar. Persaingan global dalam era digital membutuhkan lebih dari sekadar penguasaan ilmu pengetahuan, melainkan juga penguasaan berbagai keterampilan meliputi keterampilan berpikir kritis, memecahkan, mengkomunikasikan, bekerjasama, berkreasi, literasi, dankesadaran mengenai isu-isu global. (Kay, 2009; Silva, 2009; Walsh \& Sattes, 2011). Pendidikan dituntut untuk membekali siswa dengan berbagai kemampuan berpikir tingkat tinggi agar mampu menghadapi tantangan abad ke-21.

Belajar dalam pembelajaran memerlukan proses berpikir yang menurut Deluty (2004) diidentifikasi melalui pertanyaan selama proses pembelajaran untuk melatihkan berbagai keterampilan abad 21. Pendapat Deluty (2004) diperkuat oleh pernyataan Walsh dan Sattes (2011) bahwa pertanyaan yang diajukan siswa merupakan tanda keterlibatan siswa dalam belajar dan berpikir. Pertanyaan merupakan indikator proses berpikir karena berpikir tidak didorong oleh pendapat atau jawaban, namun oleh pertanyaan. Pembelajaran biologi yang ideal dikembangkan sesuai hakikat pembelajarannya yaitu ke arah pengembangan proses, produk, dan sikap (Carin dan Sund, 1990).

Biologi sebagai bagian dari sains tidak lepas dari tiga komponen dasar yaitu biologi sebagai proses, produk, dan sikap. Biologi sebagai proses terlihat dalam proses berpikir seseorang untuk menemukan dan mengembangkan sendiri tentang apa yang sedang dipelajari. Biologi sebagai produk diartikan bahwa biologi merupakan ilmu 
pengetahuan yang terorganisir terdiri dari konsep, hukum, prinsip, dan teori. Biologi sebagai sikap merupakan perilaku yang muncul ketika seseorang melakukan proses ilmiah seperti teliti, obyektif, dan jujur dalam mengumpulkan dan menganalisa data.

Kemampuan berpikir penting untuk diberdayakan karena siswa akan menemui gejala dan fenomena yang kemudian melahirkan pertanyaan-pertanyaan sebagai permasalahan yang perlu dipecahkan. Apabila kegiatan belajar mengajar masih sekedar mentransfer konsep dan siswa hanya menghafal tanpa ikut terlibat aktif, siswa akan mengalami kesulitan dalam menyelesaikan tentang fenomena yang muncul. Hal tersebut menunjukkan bahwa pembelajaran yang dilaksanakan masih berorientasi pada produk bukan pada proses. Kegiatan pembelajaran khususnya mata pelajaran biologi selain berorientasi pada hasil, sebaiknya juga berorientasi pada proses. Pembelajaran biologi merupakan bagian dari ilmu sains yang baik seharusnya dapat membuat siswa terlibat dalam proses berpikir dengan memecahkan masalah untuk menemukan konsep melalui serangkaian keterampilan proses sains (KPS).

Namun demikian pembelajaran biologi yang terorientasi pada produk cenderung bersifat teoretis, hanya sekedar mentransfer pengetahuan kepada siswa. Pembelajaran cenderung kurang melibatkan siswa secara langsung dalam kegiatan belajar mengajar, menyebabkan siswa tidak bisa menemukan sendiri konsep yang dipelajari. Siswa kurang diberi kesempatan untuk menemukan konsep dan fakta melalui pecobaan atau eksperimen di laboratorium. Kegiatan pembelajaran yang masih menggunakan paradigma teacher-centered, tidak memberi kesempatan siswa untuk mengeksplorasi dan membangun konsep ilmu pengetahuannya sendiri. Siswa cenderung pasif dan tidak mengoptimalkan kemampuan berpikir yang dimilikinya.

Fakta di lapangan masih menunjukkan bahwa proses pembelajaran biologi masih belum berorientasi pada pengembangan KPS terutama kemampuan bertanya. Siswa kurang terlatih menemukan konsep melalui pemecahan masalah, akibatnya kemampuan bertanya siswa kurang berkembang.

Akibatnya, siswa bersifat pasif dalam proses pembelajaran. Kemampuan berpikir siswa cenderung rendah dan kurang aktif dalam mengajukan pertanyaan saat proses pembelajaran berlangsung. Siswa tidak dapat menjadi seorang pelajar mandiri yang dapat menyelesaikan masalahmasalah yang ada dengan pengetahuan yang dimilikinya. Hal ini tentu saja tidak membantu siswa untuk mengembangkan kemampuan berpikirnya, tetapi hanya memindahkan informasi pengetahuan dari guru ke siswa. Pembelajaran yang berbasis hafalan, siswa tidak dituntut untuk bertanya sehingga kemampuan bertanya siswa rendah (Rendi, dkk., 2012).

Dengan demikian diperlukan metode atau model pembelajaran inovatif yang mendorong siswa dalam mengembangkan KPS terutama kemampuan bertanya. Kegiatan penyelidikan ilmiah yang dilandasi oleh kegiatan bertanya ditemui selama proses pembelajaran penemuan (discovery learning) yang diperkuat oleh Kahlr \& Nigam (2004) bahwa discovery learning merupakan pembelajaran konstruktivis yang dilakukan dengan mengkonstruksi fenomenafenomena melalui penyelidikan berdasarkan prosedur ilmiah untuk menemukan suatu pemahaman mengenai fenomena yang disajikan dalam pembelajaran.

Kekurangan dari discovery learning yaitu faktor waktu, belajar penemuan memerlukan banyak waktu karena dimulai dari perumusan masalah kemudian melaksanakan sebuah pengamatan untuk menemukan konsep (Smaldino, et al., 2011). Berpikir lateral membantu siswa pada tahap perumusan masalah (orientation), dimana siswa diarahkan berpikir secara kreatif terhadap fenomena yang dihadapi. Pada tahap eksperimen (hypothesis testing) siswa juga diarahkan berpikir lateral untuk membuat keimpulan dari data yang diperoleh.

Penerapan model discovery learning dengan metode lateral thinking diharapkan siswa termotivasi untuk berpartisipasi aktif dalam proses pembelajaran terutama kemampuan bertanya yang merupakan bagian dari serta mendorong siswa berpikir melalui pemecahan masalah dan akhirnya dapat mengkonstruk konsep secara mandiri. Selain itu siswa lebih mengutamakan ide-ide dalam berpikir untuk mengajukan pertanyaan.

Berdasarkan latar belakang tersebut, maka perlu dilakukan penelitian dengan judul: "Pengaruh Model Discovery Learning dengan Metode Lateral Thinking terhadap Kemampuan Bertanya Siswa Kelas X IPA SMAN 2 Karanganyar".

\section{METODE PENELITIAN}

Penelitian ini termasuk dalam penelitian eksperimen semu (quasi experimental research). Variabel bebas dalam penelitian ini adalah model pembelajaran melalui discovery learning dengan metode lateral thinking untuk kelas eksperimen dan pembelajaran berbasis diskusi, tanya jawab dan presentasi untuk kelas kontrol, sedangkan variabel terikatnya adalah kemampuan bertanya

Penelitian ini menggunakan desain posttest only with non-equivalent groups. Desain penelitian ini menggunakan dua kelompok, kelompok eksperimen dan kelompok kontrol. Kelompok eksperimen diberi perlakuan dengan penerapan model discovery learning dengan metode lateral thinking, sedangkan kelompok 
kontrol diberi perlakuan dengan model pembelajaran berbasis diskusi, tanya jawab dan presentasi.

Populasi dalam penelitian ini adalah seluruh siswa kelas X IPA SMAN 2 Karanganyar Tahun Pelajaran 2015/2016 sebanyak empat kelas. Sampel dalam penelitian ini terdiri dari dua kelas, yaitu kelas X IPA 2 sebagai kelas eksperimen dengan jumlah 38 siswa dan kelas X IPA 3 sebagai kelas kontrol dengan jumlah 39 siswa Teknik pengambilan sampel yang digunakan pada penelitian ini adalah cluster sampling, yaitu sampel yang diambil merupakan bentuk kelompok dan bukan individu-individu yang sama. Sampel yang diambil sebanyak dua kelas yang akan diperlakukan sebagai kelas kontrol dan kelas eksperimen. Analisis penelitian dilakukan bukan dalam bentuk individu tetapi kelas atau kelompok dengan sejumlah individu (Sudjana, 2010).

Variabel bebas dalam penelitian ini adalah model pembelajaran meliputi discovery learning dengan metode lateral thinking dan model konvensional. sedangkan yang menjadi Variabel terikat dalam penelitian ini adalah kemampuan bertanya siswa

Teknik pengumpulan data menggunakan teknik tes dan teknik non tes. Pengetahuan siswa diukur dengan mengembangkan tes berupa tes uraian. Tes uraian tersebut berupa soal kognitif untuk mengukur ranah pengetahuan siswa dan teknik nontes melalui Observasi dapat mengukur atau menilai kemampuan bertanya yaitu dengan menggunakan lembar observasi kemampuan bertanya siswa serta keterlaksanaan rencana pelaksanaan pembelajaran. Uji normalitas data kemampuan bertanya untuk kelas kontrol dan kelas eksperimen dilakukan menggunakan uji Kolmogorov-Smirnov dengan $\alpha=0,050$ dan dibantu program SPSS 17. Uji Homogenitas data kemampuan bertanya menggunakan uji Levene's dengan $\alpha=0,050$ dan dibantu program SPSS 17 . Uji hipotesis menggunakan uji-t dengan SPSS 17.

Instrumen penelitian dilakukan uji validasi isi dan instrumen. Uji validasi isi dan instrumen juga divalidasi konstruk oleh ahli.

\section{HASIL DAN PEMBAHASAN}

Data hasil penelitian diperoleh melalui teknik tes dan observasi. Hasil observasi oleh 4 orang observer. Hasil nilai rata-rata disajikan dalam Tabel 1.
Tabel 1 Distribusi Nilai Pertanyaan Meminta Penjelasan

\begin{tabular}{ccc}
\hline & $\begin{array}{c}\text { Eksperimen } \\
\text { (X IPA 2) }\end{array}$ & $\begin{array}{c}\text { Kontrol } \\
\text { IPA 3) }\end{array}$ \\
\hline Rata-rata & 0,57 & 1,54 \\
Standar & 2,48 & 3,27 \\
deviasi & & \\
Variansi & 6,17 & 10,71 \\
Minimum & 00,00 & 00,00 \\
Maksimum & 11,11 & 8,33 \\
\hline Median & 00,00 & 00,00 \\
\hline
\end{tabular}

Tabel 2 Disrtribusi Nilai Pertanyaan Apa, Mengapa, Bagaimana.

\begin{tabular}{ccc}
\hline & $\begin{array}{c}\text { Eksperimen } \\
\text { (X IPA 2) }\end{array}$ & $\begin{array}{c}\text { Kontrol } \\
\text { IPA 3) }\end{array}$ \\
\hline Rata-rata & 41,03 & 36,18 \\
Standar & 18,76 & 17,14 \\
deviasi & & \\
Variansi & 351,88 & 293,83 \\
Minimum & 00,00 & 00,00 \\
Maksimum & 66,67 & 75,00 \\
\hline Median & 44,44 & 33,33 \\
\hline
\end{tabular}

Tabel 3 Pertanyaan Berlatar Belakang Hipotesis

\begin{tabular}{ccc}
\hline & $\begin{array}{c}\text { Eksperimen } \\
\text { (X IPA 2) }\end{array}$ & $\begin{array}{c}\text { Kontrol } \\
\text { IPA 3) }\end{array}$ \\
\hline Rata-rata & 29,06 & 40,13 \\
Standar & 20,49 & 18,24 \\
deviasi & & \\
Variansi & 419,85 & 332,70 \\
Minimum & 00,00 & 00,00 \\
Maksimum & 66,67 & 75,00 \\
\hline Median & 33,33 & 41,67 \\
\hline
\end{tabular}

Tabel 4 Distribusi Nilai Kemampuan Bertanya Siswa

\begin{tabular}{ccc}
\hline & $\begin{array}{c}\text { Eksperimen } \\
\text { (X IPA 2) }\end{array}$ & $\begin{array}{c}\text { Kontrol } \\
\text { IPA 3) }\end{array}$ \\
\hline Rata-rata & 70,66 & 75,88 \\
Standar & 10,35 & 8,83 \\
deviasi & & \\
Variansi & 107,11 & 78,03 \\
Minimum & 55,56 & 58,33 \\
Maksimum & 88,89 & 91,67 \\
\hline Median & 66,67 & 75,00 \\
\hline
\end{tabular}

Berdasarkan hasil uji hipotesis yaitu keputusan uji sig $<0,050$ sehingga $\mathrm{H}_{0}$ ditolak dan $\mathrm{H}_{1}$ diterima. Hal ini berarti perolehan rata-rata nilai kemampuan bertanya siswa antara kelompok kontrol dengan kelompok eksperimen berbeda nyata. Artinya dapat diketahui bahwa ada pengaruh penerapan model discovery learning dengan metode lateral thinking terhadap kemampuan bertanya siswa kelas X IPA SMAN 2 Karanganyar Tahun Pelajaran 2015/2016.

Kemampuan bertanya siswa pada proses pembelajaran berdampak pada kemampuan siswa 
dalam menjawab pertanyaan soal kognitif pada tes akhir. Menurut teori belajar Piaget seseorang akan mengasimilasi dan mengakomodasi pengetahuan yang ada disekitarnya. Pada pembelajaran discovery learning dengan metode lateral thinking dalam penelitian yang telah dilakukan mengarahkan siswa untuk mengasimiliasi yaitu siswa menemukan konsep dari pengamatan yang konkret dan dikaitkan dengan pemahaman kognitif yang dimiliki siswa yang berkaitan dengan hal yang diamati kemudian siswa akan mengakomodasi dengan mengabstraksi konsep baru ke dalam pikirannya menggunakan katakatanya sendiri. Siswa yang mendapatkan konsep sendiri akan bertahan lebih lama dan akan lebih bermakna sehingga dapat meningkatkan retensi siswa. Menurut teori Brunner siswa dapat berperan secara aktif untuk menemukan konsep sendiri sehingga materi yang dipelajari akan lebih mudah dipahami dan dikembangkan oleh siswa (Dahar, 2006).

Model discovery learning dengan metode lateral thinking merupakan sebuah inovasi dalam pembelajaran biologi sehingga menghasilkan sintaks pembelajaran baru. Hasil pengamatan menunjukkan siswa lebih termotivasi dalam proses pembelajaran. Sintaks model discovery learning dengan metode lateral thinking membuat siswa termotivasi untuk berpartisipasi aktif dalam proses pembelajaran terutama kemampuan bertanya yang merupakan bagian dari serta mendorong siswa berpikir melalui pemecahan masalah dan akhirnya dapat mengkonstruk konsep secara mandiri. Selain itu siswa lebih mengutamakan ide-ide dalam berpikir untuk mengajukan pertanyaan. Penerapan model discovery learning dengan metode lateral thinking dikontrol melalui lembar observasi keterlaksanaan sintaks. Hasilnya menunjukkan bahwa semua sintaks telah terpenuhi sehingga guru dapat melaksanakan pembelajaran sesuai dengan komponen yang ada. Sintaks dari model discovery learning dengan metode lateral thinking mengkondisikan siswa untuk melakukan kegiatankegiatan ilmiah siswa untuk mengembangkan KPS terutama kemampuan bertanya serta keterampilan sosial dalam kelompok. KPS perlu dikembangkan karena mengandung keterampilan kognitif sekaligus keterampilan intelektual dan sosial (Rustaman, 2005). Kemampuan bertanya merupakan salah satu bagian dari KPS yang melibatkan proses berpikir. Pengembangan kemampuan bertanya dalam KPS diharapkan membuat siswa lebih aktif dalam proses pembelajaran. Menurut Chin (2004), bertanya adalah kunci belajar aktif dan bermakna yang merupakan landasan penyelidikan ilmiah. Kegiatan penyelidikan ilmiah dilandasi oleh kegiatan bertanya yang ditemui selama proses pembelajaran penemuan (discovery learning).
Kegiatan pembelajaran pada kelompok kontrol, guru menjelaskan sebagian besar materi keanekaragaman hayati di Indonesia dengan ceramah, sehingga menjadikan siswa cenderung pasif karena hanya sekedar mentransfer pengetahuan kepada siswa. Kemampuan berpikir siswa cenderung rendah dan kurang aktif dalam mengajukan pertanyaan saat proses pembelajaran berlangsung. Siswa tidak dapat menjadi seorang pelajar mandiri yang dapat menyelesaikan masalahmasalah yang ada dengan pengetahuan yang dimilikinya. Hal ini tentu saja tidak membantu siswa untuk mengembangkan kemampuan berpikirnya, tetapi hanya memindahkan informasi pengetahuan dari guru ke siswa. Pembelajaran yang berbasis hafalan, siswa tidak dituntut untuk bertanya sehingga kemampuan bertanya siswa rendah (Rendi, dkk., 2012). Pada model pembelajaran berbasis diskusi, tanya jawab dan presentasi, siswa berdiskusi secara berkelompok untuk mengerjakan lembar kerja siswa dan disertai pertanyaan-pertanyaan kepada siswa, kemudian siswa menjawab pertanyaan yang diajukan guru. Perhatian dan minat siswa di dalam proses pembelajaran juga kurang, banyak siswa yang cenderung berbicara sendiri, melamun, tidak memperhatikan pelajaran. Suasana pembelajaran menjadi kurang bersemangat, monoton, dan menjenuhkan. Model pembelajaran di kelompok kontrol kurang mengakomodasi dalam membangun pengetahuan siswa karena tidak berbasis metode ilmiah sehingga KPS kemampuan bertanya siswa kelompok kontrol lebih rendah daripada kelompok eksperimen.

\section{KESIMPULAN}

Berdasarkan hasil penelitian tentang pengaruh model discovery learning dengan metode lateral thinking terhadap kemampuan bertanya siswa kelas X IPA SMAN 2 Karanganyar dapat disimpulkan bahwa model discovery learning dengan metode lateral thinking berpengaruh terhadap kemampuan bertanya siswa kelas X IPA SMAN 2 Karanganyar.

\section{DAFTAR PUSTAKA}

Agung Nugraha, Wijang. (2012). Peningkatan Kreativitas Desain Dengan Penerapan Metode Lateral Thinking Pada Mata Pelajaran Cetak Saring Siswa Kelas Xi Kria Tekstil Smk N 9 Surakarta Semester Gasal Tahun Ajaran 2011/2012. Jurnal Pendidikan Seni Rupa FKIP Universitas Sebelas Maret, Diperoleh 13 januari 2016, dari https://core.ac.uk/download/files/478/12346044.p df

Alamolhodaei, Hassan . (1996). Convergent / Divergent Cognitive Styles And Mathematical Problem Solving. International Journal. Ferdowsi University of Mashhad, Iran. Diperoleh 17 Juni 
2016

dari http://www.recsam.edu.my/R\&D_Journals/YEA R2001/2001Vol24No2/102-117.pdf

Anderson, L. W., \& Krathwohl, D. R. (2001). A Taxonomy for Learning, Teaching, and Assessing: A Revision of Bloom's Taxonomy of Educational Objectives. New York: Addison Wesley Longman.

Arikunto, S. (2010). Prosedur Penelitian: Suatu Pendekatan Praktik. Jakarta: Rineka Cipta.

Asmin. 2005. "Implementasi berpikir lateral dalam proses pembelajaran di sekolah". Jurnal Pendidikan dan Kebudayaan, 11 (55), 525-553. Diperoleh 3 Januari 2016, dari http://library.um.ac.id/majalah/index.php?\&mod $=\mathrm{b} \& \mathrm{cat}=1 \&$ start $=0 \&$ page $=10 \& \mathrm{~s} \_$data $=\mathrm{bp} \_$index \&s_field=1\&s_teks=berpikir

Aunurrahman. (2012). Belajar dan Pembelajaran. Bandung: Alfabeta.

Balim, A. G. (2009). The Effects of Discovery Learning on Students' Success and Inquiry Learning Skills. Eurasian Journal of Educational Research (35), 1-20. Diperoleh 13 Januari 2016, dari http://wiki.astrowish.net/images/e/e1/QCY520_D esmond J1.pdf .

Blosser, P. E. (2000). Ask the Right Questions. NSTA Press. Diperoleh 13 Januari 2016, dari http://www.google.com/books?hl=id\&lr=\&id=sE GEfO7C62sC\&oi=fnd\&pg=PA2\&dq=Ask+the+ Right+Questions\&ots=PpBifKg9d\&sig=cCAvgk TTsaw9TKjXlpRzcmPKSio.

Budiyono. (2009). Statistika untuk Penelitian. Surakarta: UNS Press

Carin \& Sund. (1990). Teachung Science Through Discovery. New York: Merrill Publishing Company. New York: Merrill Publishing Company.

Coffey, H. (2009). Discovery Learning. North Carolina: Learn INC The University of North Carolina.

Chin, C. (2001). Learning in Science: What Do Students' Questions Tell Us About Their Thinking? Education Journal , XXIX (2), 85-103. Diperoleh 13 Januari 2016, dari http://repository.nie.edu.sg/jspui/handle/10497/4 734.

Chin, C. (2004). Students' Questions: Fostering a Culture of Inquisitiveness in Science Classrooms. LXXXVI (314), 107-112. Diperoleh 13 Januari 2016 ,

dari http://repository.nie.edu.sg/jspui/handle/10497/2 92.

Chin, C., \& Chia, L.-G. (2006). Problem-Based Learning: Using III-Structured Problem in Biology Project Work. Science Education , XC (1), 44-67. Diperoleh 14 Januari 2016, dari http://onlinelibrary.wiley.com/doi/10.1002/sce.20 097/abstract.

Chin, C., \& Osborne, J. (2008). Student's Questions: a potential resource for teaching and learning science. In C. Chin, \& J. Osborne, Studies in Science Education (pp. 1-39). London: Routledge.

Chouinard, M. M., Harris, P. L., \& Maratsos, M. P. (2007). Children's Questions: A Mechanism for Cognitive Development. Monographs of the Society for Research in Child Development,
LXXII (286). Diperoleh 14 Januari 2016, dari http://www.jstor.org/stable/30163594.

Cruickshank, D. R., Jenkins, D. B., \& Metcalf, K. K. (2009). The Act of Teaching. New York: The McGraw-Hill Companies.

Dahar, Ratna Wilis. (2006). Teori-Teori Belajar \& Pembelajaran. Jakarta: Erlangga. (2011). Teori-Teori Belajar dan Pembelajaran. Jakarta: Erlangga.

Darmadi, H. (2011). Metode Penelitian Pendidikan. Bandung: Alfabeta.

De Bono, Edward. (2007). Revolusi Berpikir. Bandung: Kaifa

Deluty, E. W. (2004). Cultivating The Habit of Inquiry. The Nea Higher Educational Journal , 107-112.

Ewing, J. C., \& Whiitington, M. S. (2007). Types and Cognitive Levels of questions asked by Professors During College of Agricultures Class Sessions. Journal of Agricultural Education, ILVIII, 91-99. Diperoleh 13 Januari 2016, dari http://eric.ed.gov/?id=EJ840135 .

Gulo, W. (2002). Strategi Belajar-Mengajar. Jakarta: Gramedia Widiasarana Indonesia.

Haryadi, Leo Sutrisno, Haratua T.M.S. (2013). Implementasi Kurikulum 2013 Pada Pembelajaran Fisika Di Kelas X Sma Kemala Bhayangkari Kabupaten Kubu Raya. Jurnal Penelitian Pendidikan Fisika. FKIP Universitas Tanjungpura Pontianak. Diperoleh 3 Januari 2016,

dari http://download.portalgaruda.org/article.php?arti cle $=296978 \& \mathrm{val}=2338 \&$ title $=$ IMPLEMENTASI \%20KURIKULUM\%202013\%20PADA\%20PE MBELAJARAN\%20FISIKA\%20DI\%20KELAS $\% 20 X \% 20$ SMA\%20KEMALA\%20BHAYANG KARI\%20KABUPATEN\%20KUBU\%20RAYA

Haryanto. (2015). Pembelajaran Konstruktivistik Meningkatkan Cara Berpikir Divergen Siswa SD. Jurnal Penelitian. Universitas Negeri Yogyakarta. Diperoleh 3 Januari 2016, dari http://journal.uny.ac.id/index.php/jpip/article/vie $\mathrm{w} / 4927$

Ilahi, M. T. (2012). Pembelajaran Discovery Strategy \& Mental Vocational Skill. Jogjakarta: DIVA Press.

Jacobsen, David A., Eggen, Paul, and Kauchak, Donald. (2009). Methods for Teaching, Metode-metode Pengajaran Meningkatkan Belajar Siswa TKSMA

(Edisi ke-8). Yogyakarta: Pustaka Pelajar.

Juliawan, Didik. (2012). Pengaruh Model Pembelajaran Berbasis Masalah Terhadap Pemahaman Konsep dan Keterampilan Proses Sains Siswa Kelas XI IPA SMA Negeri 2. Jurnal Penelitian Pascasarjana Undiksha. 2(1). Kuta Tahun Pelajaran 2011/2012.

Kay, K. (2009). Middle School Preparing Young People for 21 ;st Century Life and Work. Middle School Journal , 41-45.

Kemdikbud. (2012). Uji Publik Kurikulum 2013, Penyederhanaan Tematik-Integratif. Diperoleh 3 Januari 2016, dari www.kemdiknas.go.id/kemdikbud/uji-publikkurikulum-2013-1.

Klahr, D., \& Nigam, M. (2004). The Equivalence of Learning Paths in Early Science Instruction: Effects of Direct Instruction and discovery 
Learning. Psycological Science , XV (10), 661667. Diperoleh 3 Januari 2016, dari http://pss.sagepub.com/content/15/10/661.short.

Leonard. (2013). Peran Kemampuan Berpikir Lateral Dan Positif Terhadap Prestasi Belajar Evaluasi Penididikan. Jurnal Penelitian FTMIPA Universitas Indraprasta PGRI. Diperoleh 3 Januari 2016, dari http://download.portalgaruda.org/article.php?arti $\underline{\text { cle }=102532 \& \text { val }=445}$

Lestari, Yugie Puji. (2012). Penerapan Keterampilan Bertanya Untuk Meningkatkan Hasil Belajar Biologi Sub Pokok Bahasan Vertebrata Di Sma Kelas X Darussalam Indramayu. Skripsi IAIN Syekh Nurjati Cirebon.(tidak diterbitkan).

Mafikha Sari, Ida. (2015). Penggunaan Model Listening Team Sebagai Sarana Meningkatkan Kemampuan Bertanya Pada Pembelajaran Ipa Siswa Kelas X Smk Yp 17-2 Madiun. Jurnal Penelitian IPA Madrasah Aliyah Negeri 2 Ngawi hal 23-28. Diperoleh 3 Januari 2016, dari http://download.portalgaruda.org/article.php?arti cle $=359971 \& \mathrm{val}=8256 \&$ title $=$ PENGGUNAAN \%20MODEL\%20LISTENING\%20TEAM\%20S EBAGAI\%20SARANA\%20MENINGKATKAN \%20KEMAMPUAN\%20BERTANYA\%20PAD A\%20PEMBELAJARAN\%20IPA\%20SISWA\% 20KELAS\%20X\%20SMK\%20YP\%20172\%20MADIUN

Margono. (2010). Metodologi Penelitian Pendidikan. Jakarta: Rineka Cipta.

Muhidin, S.A. dan Abdurahman, M. (2009). Analisis Korelasi, Regresi, dan Jalur dalam Penelitian. Bandung: Pustaka Setia.

Muijs, D., \& Reynolds, D. (2008). Effective Teaching. Yogyakarta: Pustaka Pelajar

Moore, K. D. (1999). Middle and Secondary School Instructional Methods (2nd Edition ed.). New York: McGraw-Hill College A Division of The Mc-Graw-Hill Companies.

Nur, M. (2011). Model Pembelajaran Berdasarkan Masalah. Surabaya: Pusat Sains dan Matematika Sekolah UNESA.

Oh, P. S. (2010). How can Teachers Help Students Formulate Scientific Hypotheses? Some Strategies Found in Abductive Inquiry Activities of Earth Science. International Journal of Science Education , XXXII (4), 541-560. Diperoleh 4 Januari 2016, dari http://www.tandfonline.com/doi/abs/10.1080/095 00690903104457.

Pramesti, G. 2011. Aplikasi SPSS dalam Penelitian. Jakarta: Elex Media Komputindo

R. Rosnawati. (2011). Berpikir Lateral Dalam Pembelajaran Matematika. Prosiding Seminar Nasional Penelitian, Pendidikan dan Penerapan MIPA Fakultas MIPA, Universitas Negeri Yogyakarta. Diperoleh 25 Juni 2016, dari http://eprints.uny.ac.id/7184/1/PM-19\%20\%20R.\%20Rosnawati.pdf

Rendi Saputra, Chansyanah.D, Ratu Betta. R, Noor Fadiawati. (2012). Peningkatan Keterampilan Bertanya Dan Menjawab Pertanyaan Melalui Model Pembelajaran Problem Solving. Jurnal Penelitian Pendidikan Kimia Universitas Lampung. Diperoleh 4 Januari 2016, dari http://download.portalgaruda.org/article.php?arti cle $=288268 \& \mathrm{val}=7236 \&$ title $=$ PENINGKATAN \%20KETERAMPILAN\%20BERTANYA\%20D AN\%20MENJAWAB\%20PERTANYAAN\%20 MELALUI\%20MODEL\%20PEMBELAJARAN $\% 20 \% 20$ PROBLEM \%20SOLVING

Rustaman, N. Y. (2005). Strategi Belajar Mengajar Biologi. Bandung: UPI

Roestiyah N.K. (2008). Strategi Belajar Mengajar. Jakarta: Rineka Cipta.

Saab, N., van Joolingen, W. R., \& van Hout-Wolters, B. H. (2005). Communication in Collaborative Discovery Learning. British Journal of Education Psicology ,LXXV (4), 603-621. Diperoleh 4 Januari 2016, dari http://onlinelibrary.wiley.com/doi/10.1348/00070 9905X42905/full.

Silva, E. (2009). Measuring Skills for 21'st-Century Learning. Phi Delta Kappa , 630-634.

Siregar, E dan Nara, H. (2011). Teori Belajar dan Pembelajaran. Bogor: Ghalia Indonesia.

Slameto. (2010). Belajar dan Faktor - Faktor yang Mempengaruhinya. Jakarta: Rineka Cipta.

Smaldino, S., Lowther, D., \& Russel, J. (2011). Teknologi Pembelajaran dan Media untuk Belajar. Terj. Arif Rahman. Jakarta: Prenada Media Grup.

Sudjana, N. (2008). Penilaian Hasil Proses Belajar Mengajar. Bandung: Remaja Rosdakarya.

Sugiyanto. (2009). Model-model Pembelajaran Inovatif. Surakarta: UNS.

Sugiyono. (2011). Statistika Untuk Penelitian. Bandung: Alfabeta.

--.(2012). Metode Penelitian Kuantitatif, Kualitatif, dan $R \& D$. Bandung: Alfabeta.

Suwarto, WA dan Slamet, STY. (2007). Dasar-dasar Metodologi Penelitian Kuantitatif. Surakarta. UNS Press

Syutaridho. (2012). Berpikir Lateral dalam Matematika. Jurnal Penelitian Matematika Universitas Muhammadiyah Metro Diperoleh 4 Januari 2016, dari http://digilib.uinsby.ac.id/5106/5/Bab\%202.pdf

Van Joolingen, W. (1999). Cognitive tools for discovery learning. International Journal of Artificial Intelligence in Education, X. 385-397. Diperoleh 4 Januari 2016, dari http://hal.archivesouvertes.fr/hal-00197349/.

Veermans, K. (2003). Intelligent Support for Discovery Learning. Netherland: Twente University Press. Diperoleh 25 Desember 2015, dari http://doc.utwente.nl/38699/1/t000001b.pdf.

Walsh, J. A., \& Sattes, B. D. (211). Thinking Through Quality Questioning: Deepening Student Engagement. United States of America.

Widhy, P. (2013). Integrative Science untuk Mewujudkan 21 $1^{\text {st }}$ Century Skill dalam Pembelajaran IPA SMP. Proceeding seminar nasional Matematika dan Ilmu Pengetahuan Alam. Jogjakarta: FMIPA Universitas Negeri Yogyakarta.

Widodo, A. (2006). Profil Pertanyaan Guru dan Siswa dalam Pembelajaran Sains. Jurnal Pendidikan dan Pembelajaran , IV (2), 139-148. Diperoleh 14 Januari 2016, dari http://file.upi.edu/Direktori/FPMIPA/JUR. PEN D. BIOLOGI/196705271992031ARI_WIDODO/2006- 
Profil_pertanyaan_guru_dan_siswa_dalam_pelaj aran_sains.pdf.

Williams, Y. (2003). Convergent thinking: definition, examples \& quiz, Education Portal, 13(3).

Wenno, I.H. (2008). Stategi Belajar Mengajar Sains Berbasis Kontekstual. Yogyakarta: Inti Media. 